\title{
A REVIEW OF THEORETICALAND EMPIRICAL RESEARCH ON HUMAN CAPITAL QUALITY IN CROATIA
}

\section{Katarina Justić Jozičić, Marinko Škare}

(1) Juraj Dobrila University of Pula, Faculty of Economics and Tourism "Dr Mijo Mirković"

(2) Juraj Dobrila University of Pula, Faculty of Economics and Tourism "Dr Mijo Mirković"

\begin{tabular}{|c|c|}
\hline \multirow[t]{2}{*}{ aculty of Economics and } & $\begin{array}{l}\text { Katarina Justić Jozičić } \\
\text { xraj Dobrila University of Pula, } \\
\text { d Tourism "Dr Mijo Mirković" } \\
\text { katarina.justic@pu.t-com.hr }\end{array}$ \\
\hline & $\begin{array}{r}\text { Article info } \\
\text { Paper category: Review paper } \\
\text { Received: } 13.6 .2016 . \\
\text { Accepted: } 15 \cdot 7 \cdot 2016 . \\
\text { JEL classification: J24 }\end{array}$ \\
\hline
\end{tabular}




\begin{abstract}
Human capital is an important factor of economic growth. Its quality affects the level of available labour's competitiveness. The aim of this paper is to determine human capital quality in Croatia. This paper also tends to indicate the human capital factors in Croatia. Human capital quality is determined by the quality of the education system, than the investment in education and also participation rates in education. When considering the education quality, mainly is to observe the quality of the formal education. The quality of Croatian education system can be measured by quantitative indicators such as numbers of completed years of schooling. But also, by qualitative indicators, which are based on an international comparative research of educational student achievement of different countries. One of these international comparative researches is PISA ${ }^{1}$ for pupils in which Croatia is included since 2006. This paper will point out the importance of investment in human capital in Croatia. Insufficient investments in human capital can become the limitation factor to economic growth. According to data from UNESCO ${ }^{2}$, the Croatian public expenditure on education in 2011 amounted to $4.16 \%$ of GDP. With that, Croatia is placed below the average 3 of OECD countries which amounted in average of $6.1 \%$ or to EU countries $5.8 \%$ of GDP. An important indicator of human capital quality is also the rate of participation of Croatian population in education. According to the last population census in 2011, Croatia has sufficient educational structure: illiterate less than $1 \%$, with only primary school about $30 \%$, most with secondaryeducation $5_{2} \%$, and the share of highly educated $16.4 \%$ (increases over $4 \%$ from the last one in 2001). This paper is primarily focused on the review and systematization of the existing literature and studies on the quality of human capital in Croatia. Many researches about the topics on human capital have been indicating to its high importance. The intention is to show if Croatia has recognised the importance of human capital and its quality in comparison to other countries.
\end{abstract}

\title{
Keywords:
}

human capital quality, formal education, investment in human capital, participation rates

1 Programme for International Student Assessment www.pisa.hr

2 http://data.uis.unesco.org/?querid $=181$

3 http://www.oecd.org/edu/Education-at-a-Glance-2014.pdf 


\section{INTRODUCTION}

Many centuries passed before the man, with his abilities, knowledge, creativity and motivation has been recognized as an important factor for economic success. As an economic resource, people are starting to get involved in the economic literature after World War II ${ }^{4}$, but there were also earlier attempts to define the role of knowledge, experience, and skills of employees. Already has A. Smith emphasized the importance of people in the production process over the division of labour and specialization; Marx mentioned the role of science and technology in production; Mill wrote about the quality of human capacity required for work; Schumpeter emphasized the need to recombine knowledge for creating new products. ${ }^{5}$ The concept of human capital is entirely developed in the '6os of the 2oth century with the work of Schultz (1961), who looks at the cost of investment in education as an investment in the future, but not as consumption. He adds that by investing in themselves people are able to expand their choices and thus improve their welfare. The key of economic development lies in its people, their skills, knowledge, experience, and health. (Schultz, 1982) Požega and Crnković (2008), on the basis of their study about the impact of continuous and long-term investments in people, their resources and physical assets to economic and social development, conclude that investing in people and their resources can lead to constant and stable economic growth.

Perceiving the importance of human capital, many countries have tried to measure its value in order to determine their current status, or to determine the possibility of improving the level of existing human capital (Kwon, 2009). Most economists are based on a quantitative theory of human capital, as the identification and measurement of its quality is very difficult (Schultz, 1982). Hanushek and Kimko (2000) consider the quality of education, determining economic growth in developed countries, as more important than quantity. Babić (2005) considers that the quality of human capital is determined by the education system's quality, investments in education and participation in education.

Education is considered as the main factor of human capital quality and because of it, it is very important to define the meaning of education quality. Once, it was believed that a school has a big quality if it had a large amount of resources, but today the emphasis is on cognitive and affective achievements of education (Pastuović, 2012). Those achievements are very difficult to measure. The only relevant way of measuring achievements is through reached results in international achievements tests like

4 Pastuović, N., "Edukologija: integrativna znanost o sustavu cjeloživotnog obrazovanja i odgoja", Znamen, Zagreb, (1999)

5 Stengos, T., and A. Savvides, "Human capital and economic growth", Stanford University Press, Stanford, (2009) 
PISA, TIMMS and PIRLS ${ }^{6}$, or PIAAC ${ }^{7}$. Except for qualitative indicators, the quality of education can be measured by quantitative indicators, such as schooling rate, dropouts rate, years of schooling (Pastuović, 2012); investing in education (Lowther, 2004; Babić, 2005); enrolment rates (Lowther, 2004; Šošic, 2004); literacy rates, number of lessons, school equipment (Lowther, 2004).

Since the human capital is formed in formal and non-formal education system, it is necessary to explain the formal and informal education. After formal education a person acquired a certain level of education which is publicly recognized. The formal education system in Croatia includes preschool education, primary, secondary, higher education, and lifelong learning. Non-formal education includes education for personal development, but also family education. Informal education includes self-education and self-study and it's realized by television, newspapers, libraries, workshops. (Babić, 2005)

Pastuović (2012) states that both formal and non-formal education are organized and intentional learning; while informal is unintentional and means learning through experience. He adds that according to the level of organization, formal is more organized than the non-formal, but the informal is not organised at all. Babic $(2005)$ states that investments in human capital include investment in education and training on the job, which gives the individual psycho-physical abilities, but also, not less important factor is investment in health, which can increase the productivity of an individual.

Investments in education are shown as a share in total government expenditures or as a share of GDP (Babić, 2005; Lowther, 2004; Sošić, 2004; Nikolić, 2004; Kiss, 2002). According to these indicators, Groatia is investing below the average of OECD or EU countries. In 2011 the share of total government expenditure in Croatia was $8.5^{8 \%}$, compared to OECD countries it amounts $12.9 \%$, or to EU countries $11.5 \% 0^{8}$. Investments in education in 2011 in Croatia as a share of GDP are $4.16 \%$, which is, in comparison to OECD or EU countries that have $5.6 \%$, very low ${ }^{9}$. Nikolić (2007) emphasizes the existence of a crisis in financing education in Croatia, considered as the key factor for human capital quality. He shows a series of consequences that inadequate investment in education can have on other inputs, through inadequate material conditions of education, over de-motivated teachers because of inadequate salaries, lower quality in knowledge transmission, and all of that at the end gives worse education output that will not correspond to the labour market needs.

6 Trends in International Mathematics and Science Study and Progress in International reading Literacy Study http://timssandpirls.bc.edu/

7 Programme for the International Assessment of Adult Competencies https://nces.ed.gov/surveys/piaac/ National Center for Education Statistics

8 UIS.Stat data and www.oecd.org Education at a Glance 2013

9 UIS.Stat data and www.oecd.org Education at a Glance 2013 
As an output from the educational system, the participation rate in education is used. The participation rate shows educational structure of the Croatian population from 15 years old and over (Babić, 2005) or between 25 and 64 years old (Babić, 2005; Sundać and Krmpotić, 2004; Bejaković, (2004); Šošić, 2004), but also the share of population from 25 to 64 years old participating in lifelong learning (Šošić, 2005; Sundać and Krmpotić 2004; Lowther, 2004; Šošić 2004). The last Population census $^{10}$ made in 2011 shows progress in educational structure of the population, but the structure is still, compared to other European countries, unfavourable.

This work is presented in a way that I section shows the character of human capital. It is approached through the definition of human capital. Section II lists the approaches to measuring the value of human capital, and section III illustrates the problem of measuring human capital quality. Section IV refers to the measurement of human capital in Croatia. It provides an analysis of theoretical and empirical research on the method of measuring the value and the quality of human capital in Croatia. The paper tabular presents the indicators that attempt to measure the human capital quality in Croatia. Section V lists the conclusions of various authors about the human capital quality in Croatia, separately for input in human capital, output from education, and quality indicators. The last one, section VI contains guidelines to rising up the level of human capital in Croatia.

\section{THE GHARACTER OF HUMAN CAPITAL}

The concept of human capital is a combination of human and capital, where capital refers to factors of production, and human "is the subject to take charge of all economic activities such as production, consumption, and transaction" "11. Thus understanding, Kwon (2009), human capital can be as one of the factors of production essential for creating new values: "human as a labour force." Kwon (2009) states that, if it is invested in employee's education and training, they can also create new value. According to this presumption, human capital is considered as "human as a creator," which is more important than the previous consideration. Kwon (2009) explained that the empirical studies made in the 5 os of the 2oth century, present the investment in human capital as an essential element which led to increasing individual's wages, as opposed to quantitative inputs of other factors. Investment in human capital creates additional knowledge and skills that can be transferred to certain goods and services. The accumulation of human capital through education and training affects the increase in individual's wage, company productivity and the national economy in general (Schultz, 1961). Becker (1993) believes that the human capital is

10 Population census 2011 - Croatia Bureau of Statistic http://www.dzs.hr/Hrv/censuses/census2011/ results/htm/ho1_o1_36/ho1_o1_36_RH.html

11 Kwon, D.-B., "Human capital, and its measurement." Proc. The 3rd OECD World Forum on Statistics, Knowledge and Policy, (2009). p.1 
created by investing in man and thus in his education and training, preparation for production, a healthy eating, and in migration.

The impact of human capital, explains Kwon (2009), could be analyzed from three approaches: individual, organizational and social. The individual approach refers to the ability to increase individual wage through increasing their productivity, with also better job opportunities. By creating higher competencies organizations can become more competitive. From the society approach, human capital can affect the level of democracy, respecting human rights, and political stability. Human capital is an accumulation of investment in people, where the education plays its most important role (Mankiw, 2004). Human capital consists of "all human characteristics on which depends the working efficiency of the individual and the organization, and its components are physical health, physical and mental ability, education and motivation for work and development" 12 .

Kwon (2009; according to Frank and Bernanke, 2007) defines human capital, from production-oriented perspective ${ }^{\mathrm{1} 3}$, as "an amalgam of factors such as education, experience, training, intelligence, energy, work habits, trustworthiness, and initiative that affect the value of worker's marginal product"14. Kwon (2009; according to Sheffin, 2003) defines human capital also as "the stock of skills and knowledge embodied in the ability to perform labor so as to produce economic value"15.

Bogdanović (2008) in his work tries to clarify the ambiguities about the term human capital, which is often identified with the terms of human resources and intellectual capital. A potential is considered, similar to resource, to be transformed into capital. While intellectual capital should be represented more widely than the term of human capital. In order to clarify these terms, the structure of intellectual capital at the micro and macro level is presented. According to the company level, intellectual capital is defined as "all intangible resources that are available to an organization, that give a relative advantage, and which in combination are able to produce future benefits"16. Meaning that, in the micro level, sub-components of intellectual capital are: human resources, organizational and relational resources. At the macro

12 Pastuović, N., (1999), "Edukologija: integrativna znanost o sustavu cjeloživotnog obrazovanja i odgoja", Znamen, Zagreb, p. 374

13 Kwon (2009) believes that the concept of human capital can be understood according to three aspects: the individual that includes knowledge and skills, but also education, abilities, competency, attitude and behaviour embedded in an individual; in aspect of accumulation of knowledge, it can be acquired through training and experience; in aspects of productivity human capital affects the productivity of the individual.

14 Kwon, D.-B., "Human capital, and its measurement." Proc. The 3rd OECD World Forum on Statistics, Knowledge and Policy, (2009), p.4

15 Kwon, D.-B., (2009), "Human capital, and its measurement." Proc. The 3rd OECD World Forum on Statistics, Knowledge and Policy, (2009), p.4

16 Andriessen, D. and Stam, C., "Intellectual capital of the European Union." McOaster World Congress on the Management of Intellectual Capital and Innovation. Hamilton, Ontario, Canada, (2005), p. 3 
level, according to Bontis (2004), it is usual to name the sub-components of intellectual capital with terms of human capital, process capital and market capital. $\mathrm{Hu}-$ man capital includes everything that has to do with people; like knowledge, education, competence, with the focus on education. Process capital includes non-human knowledge such as technology, computer, or communication systems, while market capital includes national relationships that create competitive atmosphere. Bontis (2004) also mentions the renewal capital relating to future intellectual wealth with emphasis on R\&D.

\section{MEASURING HUMAN CAPITAL}

It is not possible to measure directly the human capital value, and because of that, many various factors are taken into account while measuring it. Miller (1996) indicates three most common methods of measuring human capital: 1) by the cost of formal knowledge acquisition (education and training); 2) by testing human competence; 3 ) by methods of productivity assessing based on success's indicators such as: wages level, job security, job status. Pasher (2007), for measuring the value of human capital in Israel, takes into account the following indicators: share of highly educated workforce; share of scientists, technicians and engineers per 10,000 employees; share of female workers in the total working population; the national expenditure on culture and health; people's life expectancy; share of doctors in total population.

Measuring human capital tends to coverage a large number of factors which will, in the most possible credible and realistic way, present the value of people in a country. Measuring the human capital value is needed for a better understanding of factors that affect economic growth, better establishing the connections and influence of education on economic growth, easier assessment regarding the development path to the sustainable development, and for measuring productivity of the education sector. ${ }^{17}$

The most meaningful way to measure the human capital value is presented by Kwon (2009), who measures through three approaches: output-based, the costbased, and income-based. Output-based approach includes: 1) school enrolment rates (Kwon 2009; according to Barro, 1991, Barro and Lee, 1993); 2) accumulated years of schooling in according to the employee's age as education attainment (Kwon, 2009; according to Nehru, Swanson and Dubey 1993); the share of skilled adults in comparison to adults overall (Kwon 2009; according to Romer, 1990); the average number of years of education (Kwon 2009; according to Psacharopoulos and Arriagada, 1986). The cost-based approach is based on the measurement of human capital through the cumulative cost of investing in a human capital. Income-based approach is based on the return on investment in education, mainly referring to individual's income.

17 Boarini,R., D’Ercole, M. M., and Liu, G., "Approaches to Measuring the Stock of Human Capital: AReview of Country Practices", OECD Statistics Working Papers, No. 2012/04, OECD Publishing, Paris, (2012) 
Kwon (2009) explains the current measuring method of human capital value, which is based on the OECD measurements. The measurement is similar to the international comparable statistic that relates to investment in human capital, quality, and results of education. The Table 1 . bellow shows the detailed constitution of human capital measurement. The first point refers to quantitative indicators of investment in human capital. The second one shows qualitative results of investing in human capital through international comparison of academic achievement. The third refers to the results of investment in education.

Table 1.: OECD measures on human capital

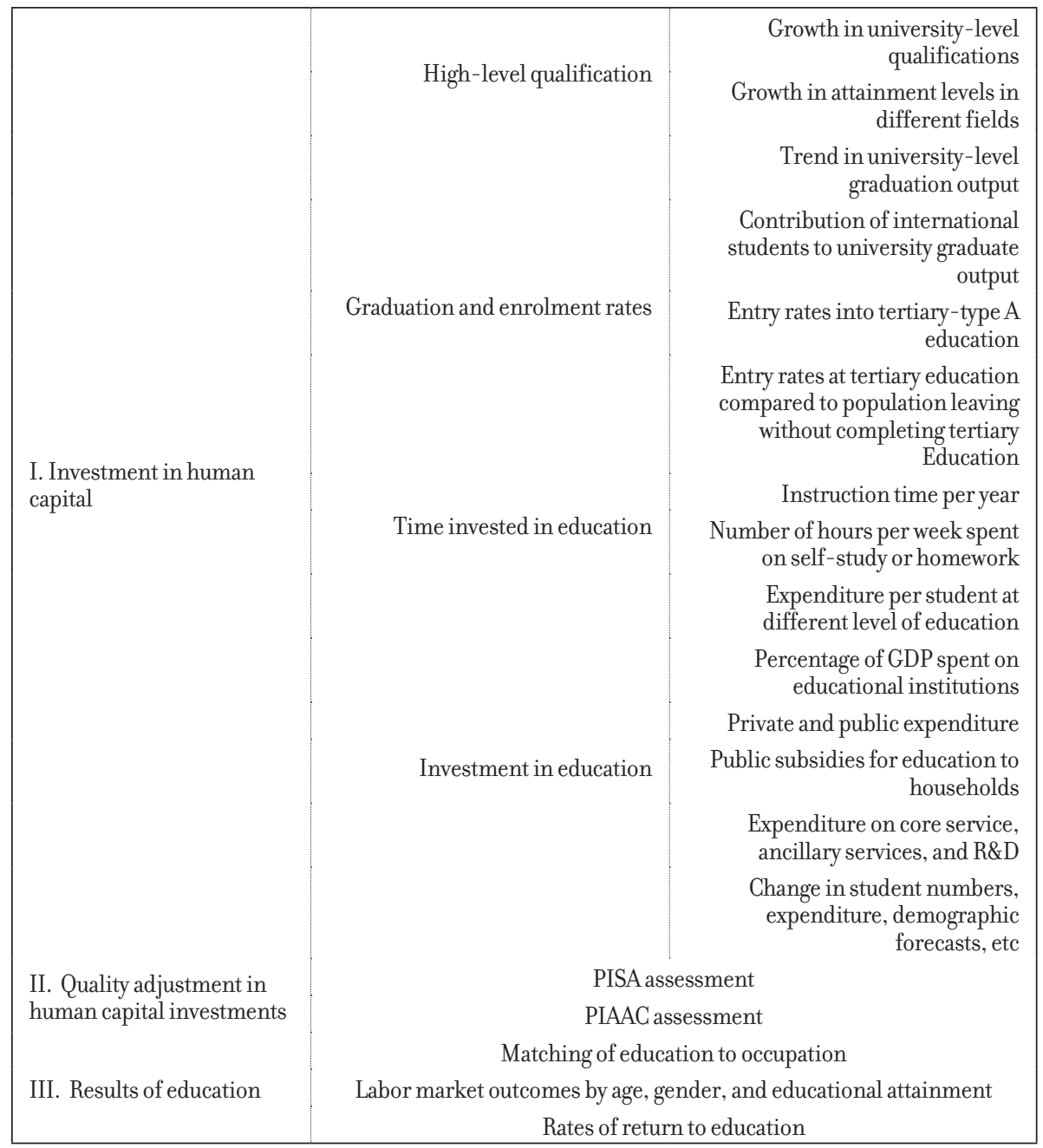

Source: Kwon (2009) p. 8 
Boarini, D'Ercole and Liu (2012) consider that the value of human capital can be measured according to: indicators-based approaches and monetary measures approaches. Indicators-based approaches can be seen as: 1) quantitative indicators such as average years of schooling; 2) qualitative indicators such as class size or the international achievements tests results. Monetary measures approaches refer to: 1) cost-benefit approach which includes investing in people according to individual view, government expenditure, and corporate investments; 2) income-based approaches measure the results of investment in people through increasing future earnings; and 3) indirect measure approaches measure "the total stock of human capital as the difference between the total discounted value of each country's future consumption flows and the sum of the tangible components of that wealth, i.e. produced capital and the market-component of natural capital" 18 .

Kwon (2009) explains that there are also other, modern views on the measurement method of human capital value. This refers to the Human Development Index $(\mathrm{HDI})^{19}$, which focuses on the quality of the individual's life and the economic situation but also on the Key Indicators of the Labour Market (KILM) ${ }^{20}$. HDI is based on health, knowledge, and living standard, including many sub-variables, while KILM is based on 17 indicators of the labour market that are based on the link between education and the process of integration into the labour market, and according to the HDI indicator, Croatia is ranked at $47^{\text {th }}$ place in the world, or at the bottom of the scale in the category Very high human development. ${ }^{21}$

\section{HUMAN CAPITAL QUALITY}

Hanushek and Kimko (2000) point to the problem of measuring the human capital quality. They indicate that the qualitative aspect of human capital can be created from two sources: 1) inputs in education which may include investments in education or teacher's wages; and 2) "student cognitive performance on various international tests of academic achievement in mathematics and science"22. Lee and Barro (2001) believe that the human capital quality can be measured by educational outputs such as results in student's cognitive skill tests, dropout rates, and repetition rates.

Altinok and Murseli (2007), in a study on a sample of 105 countries, get the comparative qualitative indicators of human capital (QIHC) which are based on

18 Boarini,R., D’Ercole, M. M., and Liu, G., "Approaches to Measuring the Stock of Human Capital: AReview of Country Practices", OECD Statistics Working Papers, No. 2012/O4, OECD Publishing, Paris, (2012), p. 14

19 http://hdr.undp.org/sites/default/files/2015_human_development_report.pdf

20 International Labour Organization http://www.ilo.org/global/publications/books/forthcomingpublications/WCMS_409035/lang--en/index.htm

21 http://hdr.undp.org/en/countries

22 Hanushek, E. A., and Kimko, D. D., "Schooling, labor-force quality, and the growth of nations." American Economic Review, (2000), p. 1185 
seven different surveys, including PISA, TIMSS, and PIRLS. Similar study has also been made by Hanushek and Kimko (2000), but on the basis of 70 countries' data. This study is based on student achievement in the field of mathematics and science. Lee and Barro's (2001) study is wider because it contains also analyses of the student achievement in the field of reading. ${ }^{23}$

As a qualitative indicator of the level of human capital, the cognitive student achievement on international tests like PISA, TIMSS, PIRLS and the PIAAC ${ }^{24}$ is mentioned. Those tests are based on testing student's achievement in the field of mathematics, science and reading. They aim at obtaining information which enables the comparison of data with other country, and at influencing on education policy, or improving education in general.

PISA is an international survey of 15 years old students in the field of mathematics, science and reading. The testing is carried out on samples of students involved in lower or upper secondary education, depending on the structure of educational system in each country. OECD project initiated due to growing necessity for internationally comparable data about on the quality of education systems and student achievement. The PISA testing is carried out in cycles of three years which allows monitoring of progress. It is focused on education policy, testing student's competence, but also on testing student's motivation for learning and learning strategy. ${ }^{25}$

IEA $^{26}$ leads two projects of international student's achievements testing and monitoring their progress in the fields of mathematics, science, and reading. Research in the field of mathematics and science is carried out under the project TIMSS ${ }^{27}$ in a cycle of four years for students of fourth and eighth grade. The aim is to improve mathematics and science teaching in elementary schools, and with comparable analysis of education policies to determine the advantages of education systems with regard to their organization, curriculum, teaching methods and student achievement. The PI$\mathrm{RLS}^{28}$ project is conducted every five years, for children after completing four years of primary education, in the field of reading, but also considering their experiences in reading, learning at school and at home. The aim is to "provide comparative data, ..,measuring trends over time, monitoring of curricular implementation and identified promising instructional practises" ${ }^{29}$.

23 The difference between those three studies is also in the kind of countries they observed. Altinok and Murseli (2007) conducted a study on a large numbers of poorest countries, while others were based on richest countries.

24. PIAAC is aimed to compare the basic skills and competences of adults in the world. Croatia is not yet included in the project.

25 www.pisa.hr

26 International Association for the Evaluation of Educational Achievement www.iea.nl

27 http://timss.bc.edu/timss2011/downloads/T11_IR_Mathematics_FullBook.pdf

28 http://timss.bc.edu/pirls2011/downloads/Pı_UserGuide.pdf p. 1 
IEA projects and PISA have different outcomes, because they are made with different purposes. PISA has orientation policy, because it measures student achievement on the way to determine the possibility of applying such knowledge and skills in practice, which provides a direct link between curriculum and the policy-makers. IEA projects have research orientation and are more focused on how to teach and learn. ${ }^{3 \circ}$

\section{IS THE VALUE OF HUMAN CAPITAL MEASURED IN CROATIA - AND HOW?}

The topic on "human capital" is very popular at the moment in Croatia, probably because it has been recognized as an important component of economic development. Research concerning human capital related to economic growth, the labour force competitiveness, education, rates of return on investments in human capital. Studies related to the measurement of the human capital value, or the determination of its quality, are present in smaller volume.

There is no exact method of measuring human capital value, and certainly not its quality, but almost all authors in Croatia agree that its value can be measured by quantitative and qualitative indicators. Quantitative indicators related to the measurement of inputs in the development of human capital, such as enrolment rates, investment in human capital, but also on outputs like schooling rate, rates of returns to education, labour market outcomes by education attainment. The qualitative aspect of human capital is based on qualitative results indicators of international student's achievement tests.

Croatia has started to participate in international testing of the effects of education only in 2006 by involvement in the PISA survey, and only in 2011 in the projects TIMSS and PIRLS. This proves that all research conducted on the subject of human capital, till that period in Croatia, did not contain an essential element of its quality, and that the measurement of student achievement in cognitive abilities was not conducted. The deficiency of the qualitative indicators and the problem of estimating the quality of the Croatian education system are indicated by Lowther (2004), Bejaković (2004), Babić (2005), Šošić (2004).

The impact of human capital on economic growth is unquestionable. Škare (2001) has proved that, in the case of Croatia, only human capital has increasing rates of return as opposed to other factors of economic growth. He emphasises the need to rely on human capital in order to achieve greater economic growth. Tica and Đukec (2008) in assessing the contribution of labour, physical, and human capital to economic growth rates in Croatia, came to conclusion that the share of human capital ${ }^{31}$ in GDP growth is $13 \%$, what is considered relatively low. Returns to education can

3o Wu, M., "Comparing the Similarities and Differences of PISA 2003 and TIMSS. OECD Education Working Papers, No. 32." OECD Publishing (NJ1), (2010).

31 The human capital index is calculated on the basic of educational level and share in earnings 
be viewed from the individual or public side and can be economic or non-economic $^{32}$. While analysing total factor productivity data in Croatia, Raguž, Tica and Družić (2012), for estimating human capital value use two ways of measuring: 1) employment and wages in different levels of educational attainment of the Croatian labour force; and 2) total years of schooling. In grow accounting model of Croatia estimated share of human capital is between $15-32 \% .33$

Human capital is an important determinant of a country's competitiveness, conclude Bejaković (2004) and Sundać and Krmpotić (2009). In an empirical research, Vokić and Frajlić (2004), the Croatian labour force competitiveness observed from the micro aspect, is identified with the value of human capital in Croatian companies. Ššsić (2004) believes that "increasing investment in human capital, i.e. education, ... is one of the priorities of the economic policy of developed countries" ${ }^{24}$, noting that human capital and education are not synonymous, because the concept of human capital also included corporate investment in people, investment in health, gained experience in the workplace. From these findings it is evident that the concept of human capital can almost relate to education, and that is probably so because education is an important factor in the creation of human capital and the education quality directly effects human capital quality. Nikolić (2007) considers that the human capital quality is "determined by the education system quality which provides the acquisition of all the necessary knowledge, skills, and competencies that are required in the labour market" ${ }^{35}$. Pastuović (2012) indicates that raising the education quality effects directly to increase of the human capital quality, which should be the aim of any advanced education policy. Šošić (2004) considers that human capital value is measured on the basis of achieved education level, where schooling years are taken into consideration, and the educational structure of the working age population, but also on the basis of qualitative indicators measured through standardized international achievements tests. He emphasizes that for forming human capital, there is a crucial influence of other factors such as education quality, non-formal education, and training. Because of that, Ššsić (2004) states that indicator of average schooling years is not an appropriate way of measuring the human capital quality.

The human capital quality in Croatia "is determined by the quality of the edu-

32 For detailed overview of economic and non-economic returns to education from individual or public approaches look in Škare, M., Kostelić, K., Justić Jozičić, K. (2013), Does Higher Education Pay off? Micro an Macroeconomic Policy Implications; The future of economics: Between rules and discretion; Juraj Dobrila University of Pula, pp. $9^{3}$ - 120;

33 Tica, J., and Grgurev, I., "Relativna važnost faktora rasta u Republici Hrvatskoj." EFZG Working Paper Series/ EFZG Serija članaka u nastajanju o2: 1-16, (2014), p. 6

34. Šošić, V.(2004), "Isplati li se u Hrvatskoj ulagati u obrazovanje: povrat ulaganja u ljudski kapital kao čimbenik konkurentnosti ljudskih resursa", Institut za javne financije http://www.ijf.hr/konkurentnost/ sosic.pdf, p. 4

35 Nikolić, N., "Financijska decentralizacija obrazovnog sustava u Hrvatskoj." Ekonomska misao i praksa 2: $213-228,(2007)$, p. 214 
cational system, investments in education and participation in education" ${ }^{36}$, wrote Babić (2005). If we compare this Babić's (2005) statement with the three segments of measuring the human capital value, which Kwon (2009) presented in the Table 1, it can be concluded that Babić (2005) used precisely these segment indicators, but to determine the quality. Nor do other authors, presented in this paper, keep away from these frames, but the fact is that no other author has taken all indications of measurement that Kwon (2009) presented.

The education system quality is determined as the output quality, where quality is effected through the quality students' competences, and as output where the quantitative indicators can be: number of persons who have completed school or study, dropout rate and the length of education (Pastuović, 2012). The importance of the formal education system quality is pointed out, as a factor that effects the development of human capital, and thus the competitiveness of human resources in Croatia (Lowther, 2004). He considers that the formal system quality is very difficult to determine, especially because Croatia does not participate in international student's achievements tests.

Pastuović (2012) indicates that there are very different opinions about the Croatian education system quality, from extremely bad to very positive, which lead him to conclusion that only objective indicators can be considered as indicators of quality, namely: knowledge tests. However, Pastuović (2012) emphasizes, how tests of knowledge results cannot be the only indicators of quality, they can affect the rational management of educational policy. To assess the education system quality, there are some essential indicators: 1) the average national results achieved on international tests in mathematics, science, and reading; 2) the level of equality in educational achievements between certain schools and the national average; 3 ) the size of socioeconomic impact on academic achievement. Pastuović (2012) further explains that the more the achievements of certain schools are closer to the national average and the smaller the impact of economic, social, and cultural status of families on educational attainment, the education system is better. To assess the education system quality in Croatia, Lowther (2004) based on the following indicators: 1) quantitative indicators such as enrolment rates, literacy rates, electronic literacy, number of classes, government expenditure in education; 2) the results of empirical research made on a sample of 300 Croatian companies whose aim was to found out if the Croatian education system creates necessary knowledge and skills for the current needs of the economy; 3) qualitative studies, particularly the OECD Reviews of National Policies for Education, where he compares the Croatian education system with other countries.

Vokić and Frajlić (2004), in their empirical research about the competitiveness of the Groatian labour force, conducted on 334. Croatian companies in 2003, put the emphasis on the measurement of human capital. They consider the following

36 Babić, Z., "Participacija i ulaganje u obrazovanje u Hrvatskoj." Privredna kretanja i ekonomska politika 14.101: $28-53$, (2005), p. 29 
indicators: 1) the knowledge and skills of employees (according to Tintor 1995; Cascio, 2000); 2) the demographic characteristics of the employees: age (according to Sveiby, 1997), years of professional work (according to Cohen and Levinthal, 1990), gender, absenteeism, fluctuation (according to Stewart, 1999; Fitz-enc, 2000); 3) investments in education and development (according to Mayo, 2001); 4) and to the subjective managers opinions. Babić (2005) analyzed the indicators of investment in education through government expenditure and company investment in additional education of their employees, and the participation rates in education including: enrolment rate and people's education structure, as factors that together with qualifying indicators of the education system, affect the quality of human capital. Sundać and Krmpotić (2009) in order to analyze the quality of human capital in Croatia consider: 1) education indicators: the share of population from 25 to 64 years old who completed at least upper secondary education (data taken from Eurostat 2008); the number of students per 1.000 inhabitants; share of the population from 25 to 64 years old who participate in lifelong learning; 2) the working-age population quality: the number of employees according to the total number of working-age population; the number of employees working on the creation of knowledge; the number of researchers employed in research and development per million inhabitants. Bejaković (2004) believes that the workforce competitiveness is determined by educational structure, compatibility of supply and demand for labour in terms of knowledge, expertise, ability, and labour costs. Beside the educational structure of the population, he considers also the number of students per 1.000 population, enrolment rates, dropout rate, and the average duration of study. Šošić (2004), when considering the return on investment in human capital touches on the quality of human capital and observes it with the following indicators: investment in education, the share of the population in education, enrolment rates, dropout rate, and the number of students per 1000 inhabitants.

In order to summarize all the indicators of human capital quality in Croatia the Table 2. is compiled where all analyzed indicators are given. It should be noted that some of the indicators are used to assess the competitiveness of the Croatian labour force, but also to evaluate the education system quality and those will be analyzed also below. In order to facilitate the managing of a large numbers of disorganised indicators, the Table 2. is divided in 3 parts: 1) Measuring the input in human capital by quantitative indicators; 2) Measuring output as results of education by quantitative indicators; and 3) Qualitative indicator. 
Table 2.: Indicators for measuring human capital quality in Croatia

\begin{tabular}{|c|c|c|c|c|c|c|c|c|c|}
\hline & INDICATORS & 龸 & 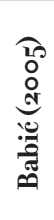 & 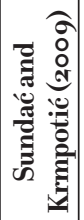 & 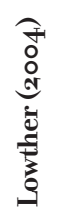 & 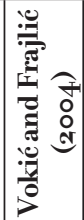 & 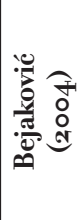 & 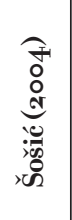 & 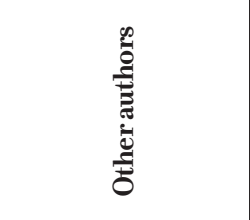 \\
\hline & Government e & $\begin{array}{l}\text { Ire on } \\
\text { ration }\end{array}$ & & & & & & * & $\begin{array}{r}\text { Nikolić (2007) Kiss } \\
(2002)\end{array}$ \\
\hline & Company investr & eople & & & & & & & Vokić and Grizelj \\
\hline & & rates & & & & & & & \\
\hline 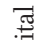 & & rates & & & & & & & Filipić (2009) \\
\hline : & The average du & study & & & & & & & \\
\hline 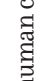 & $\begin{array}{l}\text { Nur } \\
\text { Number of oblig }\end{array}$ & $\begin{array}{l}\text { lasses } \\
\text { npare } \\
\text { biects }\end{array}$ & & & & & & & \\
\hline .્\zh24 & $\begin{array}{r}\text { The dece } \\
\text { educ }\end{array}$ & istem & & & & & & & Nikolić (2007) \\
\hline 胥 & & wage & & & & & & & \\
\hline 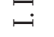 & & price & & & & & & & \\
\hline & $\begin{array}{r}\text { Possibil } \\
\text { professiona }\end{array}$ & $\begin{array}{l}\text { her's } \\
\text { ment }\end{array}$ & & & & & & & Gobo (2008) \\
\hline & Sch & ment & & & & & & & $\begin{array}{r}\text { Economic } \\
\text { Institute research } \\
(2014)\end{array}$ \\
\hline & $\begin{array}{r}\text { People educat } \\
\text { in age of } \\
\text { educatio }\end{array}$ & $\begin{array}{l}\text { icture } \\
\text { ore to } \\
\text { ment }\end{array}$ & & & & & & & \\
\hline & $\begin{array}{l}\text { People education } \\
\text { age of } 25 \text { to } 64\end{array}$ & $\begin{array}{l}\text { ure in } \\
\text { tional } \\
\text { ment }\end{array}$ & & & & & & & \\
\hline & $\begin{array}{r}\text { Share of the popu } \\
\text { to 64years old p } \\
\text { lif }\end{array}$ & $\begin{array}{l}\text { om } 25 \\
\text { ing in } \\
\text { rning }\end{array}$ & & & & & & & $\begin{array}{r}\text { Čučković and Bartlett } \\
(2012)\end{array}$ \\
\hline 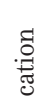 & $\begin{array}{r}\text { The number } \\
1.0\end{array}$ & $\begin{array}{l}\text { ts per } \\
\text { itants }\end{array}$ & & & & & & & $\begin{array}{r}\text { Babić, } \\
\text { Matković and Šošić } \\
(2006)\end{array}$ \\
\hline 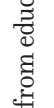 & $\begin{array}{l}\text { The numbe } \\
\text { according to th } \\
\text { of working- }\end{array}$ & $\begin{array}{l}\text { oyees } \\
\text { mber } \\
\text { lation }\end{array}$ & & & & & & & \\
\hline 递 & $\begin{array}{l}\text { The numbe } \\
\text { working on }\end{array}$ & $\begin{array}{l}\text { oyees } \\
\text { ion of } \\
\text { ledge }\end{array}$ & & & & & & & \\
\hline 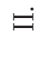 & Number of resea & itants & & & & & & & \\
\hline & & rates & & & * & & & & \\
\hline & $\begin{array}{r}\text { Electronic lit } \\
\text { numbers }\end{array}$ & $\begin{array}{l}\text { rough } \\
\text { aters) }\end{array}$ & & & & & & & \\
\hline & $\begin{array}{r}\text { Employe } \\
\text { including subjec } \\
\text { opinion } \\
\text { demographic }\end{array}$ & $\begin{array}{l}\text { (also } \\
\text { agers } \\
\text { loyee } \\
\text { istic) }\end{array}$ & & & & & & & $\begin{array}{r}\text { Economic Institute } \\
\text { research (2014) }\end{array}$ \\
\hline & $\begin{array}{r}\text { Rate } 0 \\
\text { investmer }\end{array}$ & $\begin{array}{l}\text { from } \\
\text { ation }\end{array}$ & & & & & & & \\
\hline resu & $\begin{array}{r}\text { II. Qualitative indi } \\
\text { lts on the internati } \\
\text { achievements }\end{array}$ & & & & & & & & $\begin{array}{r}\text { Pastuović (2012 } \\
\text { Čučković and Bartlett } \\
(2012))\end{array}$ \\
\hline
\end{tabular}




\section{RESEARCH RESULTS}

According to the research results, conclusions are given onwards, separately for each indicator.

\subsection{INPUT IN HUMAN CAPITAL}

Babić's (2005) tabular display presents the government expenditure on education for the period from 1997 to 2001 . He considered that expenditure for education is insufficient in comparison with OECD and EU countries. Nikolić (2007) mentions the crisis in financing the education in Croatia. Analyzing the Croatian education system, Lowther (2004), emphasises the problem of financing education because of permanently insufficiency investments, but also the problem of fairness deficiency in allocating resources. Kiss (2002) explains that there is no possibility to increase the government expenditure on education and generates a necessity for finding some other suitable solution for financing it; like sponsorships, donations, direct financing of individuals or companies, opening a large number of private schools. Šošić (2004) considers that government expenditure on education in Croatia does not deviate significantly from the average of developed countries. He explains that, if to government expenditure to education the private investment in education are also added, which amount in Croatia is still estimated $^{3} 7$, but he assumes to be at the same level as public, it is obtained an indication that could be almost on the same level as the average of developed countries. The Figure 1 presents trends in government expenditure on education, viewed in total expenditure and in share of GDP, for those years which Babic (2005) presented. The Figure contains also newer data obtained from UIS.Stat ${ }^{38}$. The data shows that the share of government expenditure on education is not drastically changed in the observed period.

Data given in Figure 1 are compared to the OECD and EU countries average. OECD countries in 2011 have an average share of government expenditure on education of $12.9 \%$ of total expenditure, while the average share of total government expenditure on education as a share of GDP was 5.6\%. EU countries have an average share of government expenditure on education of $11.5 \%$ of total expenditure, while the average share of total government expenditure as a share of GDP was also $5.6 \%$. The data indicate that Croatian government expenditure on education, as a share of total expenditures is $8.5^{8 \%}$, while the share of total government expenditure as a share of GDP was $4.16 \%$, and compared to the observed averages, is very small.

Based on the research of human resources in Croatian companies, Babić (2005, according to Marusić 1999) concludes that a small amount is invested in the further

37 Through Babić, Matković and Šošić (2006) it is estimated that private investment in high education related to GNP are $0.23 \%$, but only referring to tuition fees. Eurostudent V shows that indirect study cost are 5 time higher than the direct cost or tuition fee. 
employees' education. Companies in Croatia invest in education much less than the international and European standards, they invest only in training highly qualified employees. (Vokić and Frajlić 2004) Through research made by Vokić and Grizelj (2007) of Croatian companies' investments in employee's education, it is found that $68 \%$ of companies increased their investment, and the invested amount as a share in total income is an average of $5 \%$.

Lowther (2004) analyzes the enrolment rate in education and concludes the rates are very low in preschool education, very high in primary education, average in upper secondary, and relatively high on tertiary education. Šošić (2004) and Babić (2005) emphasize that Croatia's enrolment rates in preschool education significantly lag behind developed countries. Enrolment rate in preschool education is usually observed from 0 - 2 years old, and from $3-5$. The share of children from o - 2 years old attending preschool education are: $9.6 \%$ in 2001; $14.7 \%$ in 2008; $18.6 \%$ in 2014, and the share of children from 3 - 5 are: $44.3 \%$ in 2001; $59.4 \%$ in 2008; and $61.4 \%$ in $2014^{39}$. A significant increase is viewed, but in comparison with EU countries, which have an average enrolment rate of $90 \%$ for 4 -years old children, Croatia is placed in the group of a very low level with less than $65^{4} 4^{\circ}$. ET 2020 set a target that at least $95 \%$ of children between the ages of 4 years until they start primary school should attend preschool education. Enrolment rate in primary education are very high (Babić 2005), in average $96 \%$ in the period from 2000 to 2011 , but after 2012 it is more than $98 \%$, and in $2014,98.4 \% 4^{41}$. The enrolment in high school or tertiary education are increasing through year, but still not satisfying because of high dropout rates and large study duration. The enrolment rate in high school in the period from 2000 till 2011 is in average $85 \%$, and in 2014. 92.8\% ${ }^{42}$. There are different enrolment rates in tertiary education, depending on study programs ${ }^{4}{ }^{3}$. The student enrolment rate can be calculated for the 2011 and is $63.09 \% 44$, in comparison to $84 \%$ OECD average, or EU $87 \% 45$, it is very low. The number of students in tertiary education in 2013 is 161.911, and it is shown an increasing of $5.1 \%$ in confront to 2011.

Bejaković (2004) touched the dropout rates. He estimated that $1.5 \%$ of students do not finish high school, but believes that there is a difference in the rate of

39 UNICEF, TransMonEE Database 2015, http://www.transmonee.org/databases.php

40 Eurostat Regional Yearbook 2014 http://ec.europa.eu/eurostat/documents/3217494/5786237/KS-HA14-oo1-o3-EN.PDF/43efce65-4,b6c-4105-8c93-a6fce178c5ee?version=1.o

41 UNICEF, TransMonEE Database 2015, http://www.transmonee.org/databases.php

42 UNICEF, TransMonEE Database 2015, http://www.transmonee.org/databases.php

$4^{3}$ For detailed overview of enrolment rates in different study programs look in Horvat Novak, D., and Hunjet, A., "Analiza učinkovitosti visokog obrazovanja u Republici Hrvatskoj." Tehnički glasnik 9.4: 4.61$468,(2015)$.

44. Through Population Census 2011 Croatia has 4.284.889 habitants, in the age group 15 - 19 there are 244.177 habitants, and if the number of 154.054 students enrolled in 2011 compares to those age group, there is a share of $63.09 \%$.

45 https://www.oecd.org/edu/eag2013\%20(eng)--FINAL\%2020\%20June\%202013.pdf 
school dropout in gymnasium and vocational programs. He emphasizes a high student dropout rate. Even through numerous years of studying, only about $3 \circ \%$ of students complete their study in time. According to the number of students enrolled in the first year, only $39 \%$ of students graduate, which indicates a very high number of students who interrupt their studies. Ššić (2004) also confirmed that more than $30 \%$ of students do not finish their study. Through conducted survey in University of Split, Filipić (2009) finds out that students drop out rate is $25 \%$. ET 2020 set as aim that the dropout rate should be less than $10 \%$.

The average duration of study in Croatia is very long (Bejaković, 2004; Šošić, 2004). Bejaković (2004) states that average duration of four-year study, actually, lasts seven years and two-year higher study lasts five years.

Lowther (2004) thinks Croatian students are deprived soon at the beginning of education, because of lesser number of classes than OECD countries. The schooling of average Croatian student will last 4 years shorter, and thus the knowledge and skills they achieve through education, will be lesser than the EOCD country average.

When analyzing the Croatian education system, Lowther (2004), concluded that: the proposed strategy in Croatia has not been implemented or even realized; the education management is strictly hierarchical and the managing is inadequate; there is a large number of obligatory versus elective subjects; textbooks are too expensive according to average Croatian income; teachers' salaries are much lower than the OECD average; teachers do not have the professional development opportunities. According to the teacher's professional development opportunities, Gobo (2008) makes a research through teachers, and finds out that teachers show a greater desire for additional education more than they were offered. The Economic Institute research ${ }^{4} 6$ finds out that the biggest problem of Croatian educational system is poorly prepared plans and programs, but also unskilled teaching staff. School equipment is generally very poor (Lowther 2004; Economic Institute research 2014).

\subsection{OUTPUT FROM EDUCATION}

Babić (2005) monitored the share Croatian working-age population in education, through the National Bureau of Statistics data, and gave an overview of the changes from 1961 to the 2001 . According to these data, he concluded, the largest increase in the share of working-age population is noted by the population with secondary education. Looking at the data, the improvement in the level of human capital measured by the average number of completed years of schooling is visible. However, it is the improving structure of sufficient quality and how it is compared to other countries, Babić (2005), recognized the need for extensive research. Bejaković

46 Anić, I.D., at al., "Kako pobuditi rast Hrvatskog gospodarstva”, Ekonomski institut, Zagreb, (2014) 
(2004) also emphasized the lagging of Croatia in education compared to developed countries, but also in relation to some transition countries.

Table 3. contains the changes of Croatian working age population with data from the Population Census 2011. It shows the improvement in almost all aspects of the educational structure. The share of the population with no education and with only primary school education is decreasing, while increasing is the share of secondary and higher education.

Table 3.: Dynamics of Croatian people educational structure in age of 15 and more to educational attainment in $\%$ - for the period from 1961 - 2011

\begin{tabular}{|l|r|r|r|r|r|r|}
\hline & $\mathbf{1 9 6 1 .}$ & $\mathbf{1 9 7 1 .}$ & $\mathbf{1 9 8 1 .}$ & $\mathbf{1 9 9 1 .}$ & $\mathbf{2 0 0 1 .}$ & $\mathbf{2 0 1 1 .}$ \\
\hline $\begin{array}{l}\text { Total } \\
\text { No education } \\
\text { and to 3 grade } \\
\text { of elementary } \\
\text { education }\end{array}$ & 100.0 & 100.0 & 100.0 & 100.0 & 100.0 & 100.0 \\
$\begin{array}{l}\text { From 4, to 7grade } \\
\text { of elementary } \\
\text { education }\end{array}$ & 23.5 & 17.0 & 13.5 & 8.6 & 7.4 & 2.7 \\
$\begin{array}{l}\text { Finished } \\
\text { elementary }\end{array}$ & 53.3 & 43.6 & 31.9 & 21.2 & 11.2 & 6.9 \\
education & 8.6 & 14.8 & 19.2 & 23.4 & 21.8 & 21.3 \\
$\begin{array}{l}\text { Finished high } \\
\text { school }\end{array}$ & 12.6 & 20.4 & 28.3 & 36.0 & 47.1 & 52.6 \\
$\begin{array}{l}\text { Higher } \\
\text { education2 }\end{array}$ & 0.6 & 1.4 & 2.7 & 4.0 & 4.1 & 5.8 \\
$\begin{array}{l}\text { High education } \\
\text { Unknown }\end{array}$ & 1.2 & 2.2 & 3.6 & 5.3 & 7.8 & 10.5 \\
\hline
\end{tabular}

Source: Babić (2005), Author's through data Population Census 2011

Babic (2005) pointed out the educational structure of the population aged between 25 and 64 years old and compared them with the following transition countries: Bulgaria, Czech Republic, Hungary, Slovakia, and Slovenia. He concluded that Croatia does not significantly lag behind them according to educational structure. ${ }^{47}$ Bejaković (2004) states that increasing the share of people over 25 who have high school, higher or high education makes a positive impact on economic competitiveness and GDP growth of the country. He adds that the current education structure, especially in transition countries, unfortunately, does not guarantee the creation of competitive capabilities nor economic development, primarily because the educational systems do not respond to market needs. Sundać and Krmpotić (2009) analyzed the share of population who have completed at least high school, and till 2006 it was $71.10 \%$, and in confront to observed countries, the share does not show a terrible lag. They also pointed out the difficulty in comparing the data

47 Except Hungary, that has higher share of people with no finishing the elementary school. 
because of different education systems, which means their conclusion could not be certainly correct.

In order to present newer data, Table 4 . is compiled, which shows the share of educated population in Croatia in reference to other EU countries. ${ }^{48}$ Without formal education, Croatia has only 1.7\% of the working-age population, and compared to other mentioned countries, this is extremely low. Croatia has only $1.0 \%$ people with only primary education; Post secondary non tertiary education is $0.0 \%$; High education is much lower than the average, only $16,3 \%$; and the most expressed is the lower and upper secondary education with $52,6 \%$.

However, these data do not show the exact situation, primarily because the $\mathrm{Na}^{-}$ tional Classification of Education ${ }^{49}$ does not correspond to the International Standard Classification of Education ISCED ${ }^{\circ}$, and the reality is a bit different. In Table 4. it is attempted to present the Croatian education system through the international standards by using educational years for each degree of student's age, and then it is compared to the EU average.

A person has no formal education as long as he does not finish primary school, which means that Croatia has more than 9.6\% such as labour. Through the ISCED that refers to: no formal education, primary, a part of lower secondary, but in Croatian education system this is still with no vocation! That means, with no vocation is $30.9 \%$ of Croatian population. With finished primary education, Croatia has $21.3 \%$, which is a part of lower secondary education through the ISCED. Croatian high school corresponds to upper secondary education through ISCED, and its share is $52.6 \%$. Croatian higher education can correspond to post secondary, not tertiary through ISCED, whose share is $5.8 \%$, but not specified through ISCED while it is counted in high education. The share of high education is only $10.5 \%$ that match to first and second stage of tertiary education through ISCED. Data includes only o.3\% Ph.D.

A simple conclusion can be made on the basis of presented data in that way, which is that there are triple more people with no education or with only elementary than those with tertiary education. Only for comparison, ET $2020^{5^{1}}$ states that the share of tertiary education in the population between 25 and 65 ages should be greater than 4,0\%. Croatia is yet not even close.

48 It is given the review for only $23 \mathrm{EU}$ countries, because for the other 4 the data were not available. The European Statistical System (ESS) http://ec.europa.eu/eurostat/web/european-statistical-system

49 Croatian Bureau of Statistic Yearbook 2005 http://www.dzs.hr/Hrv_Eng/ljetopis/2005/26-met.pdf

50 The Structure of the European Education Systems 2014/15: Schematic Diagrams, European Commission http://eacea.ec.europa.eu/education/eurydice/documents/facts_and_figures/education_structures_ EN.pdf

$5^{1}$ Council conclusions of 12 May 2009 on A Strategic Framework for European Cooperation in Education and Training (ET 2020) (2009/C 119/02) http://eur-lex.europa.eu/legal-content/EN/TXT/PDF/?uri=CE LEX:52009XGo528(o1)\&from=EN 
Table 4.: Education structure of the EU population through the Population census $2011^{3}$ in compare to Croatian education system through data of Population census 2011

\begin{tabular}{|c|c|c|c|c|c|c|c|c|}
\hline $\begin{array}{l}\text { Through } \\
\text { ISCED }\end{array}$ & $\begin{array}{r}\text { No } \\
\text { formal } \\
\text { educa- } \\
\text { tion }\end{array}$ & $\begin{array}{r}\text { Pri- } \\
\text { mary } \\
\text { educa- } \\
\text { tion }\end{array}$ & $\begin{array}{l}\text { Lower } \\
\text { sec- } \\
\text { ondary }\end{array}$ & & $\begin{array}{r}\text { Upper } \\
\text { sec- } \\
\text { ondary } \\
\text { educa- } \\
\text { tion }\end{array}$ & $\begin{array}{r}\text { Post } \\
\text { sec- } \\
\text { ondary } \\
\text { non } \\
\text { tertiary } \\
\text { educa- } \\
\text { tion }\end{array}$ & $\begin{array}{r}\text { First } \\
\text { and } \\
\text { second } \\
\text { stage of } \\
\text { tertiary } \\
\text { educa- } \\
\text { tion }\end{array}$ & $\begin{array}{r}\text { Not } \\
\text { stated }\end{array}$ \\
\hline $\begin{array}{l}\text { EU } \\
\text { average }\end{array}$ & 3.2 & 12.5 & 24.1 & & 35.9 & 1.9 & 21.4 & 1.0 \\
\hline Croatia & 1.7 & 1.0 & 28.2 & & $5^{2} .6$ & 0.0 & 16.3 & 0.2 \\
\hline $\begin{array}{l}\text { Through } \\
\text { National } \\
\text { Classifi- } \\
\text { cation of } \\
\text { Education }\end{array}$ & $\begin{array}{r}\text { No } \\
\text { formal } \\
\text { educa- } \\
\text { tion }\end{array}$ & $\begin{array}{r}\text { To } 3 \\
\text { grade } \\
\text { of el- } \\
\text { emen- } \\
\text { tary } \\
\text { educa- } \\
\text { tion }\end{array}$ & $\begin{array}{r}\text { From } \\
4 \text { to } 7 \\
\text { grade } \\
\text { of el- } \\
\text { emen- } \\
\text { tary } \\
\text { educa- } \\
\text { tion }\end{array}$ & $\begin{array}{r}\text { Fin- } \\
\text { ished } \\
\text { el- } \\
\text { emen- } \\
\text { tary } \\
\text { educa- } \\
\text { tion }\end{array}$ & $\begin{array}{l}\text { Fin- } \\
\text { ished } \\
\text { high } \\
\text { school }\end{array}$ & $\begin{array}{l}\text { Higher } \\
\text { educa- } \\
\text { tion }\end{array}$ & $\begin{array}{r}\text { High } \\
\text { educa- } \\
\text { tion }\end{array}$ & $\begin{array}{r}\text { Not } \\
\text { stated }\end{array}$ \\
\hline Croatia & 1.7 & 1.0 & 6.9 & 21.3 & $5^{2.6}$ & 5.8 & 10.5 & 0.2 \\
\hline Croatia & \multicolumn{4}{|c|}{30.9} & 52.6 & 5.8 & 10.5 & 0.2 \\
\hline
\end{tabular}

Source: Authors through data from European Statistical System 2011 (ESS), Croatian Population Census 2011 and International Standard Classification of Education ISCED 2011

According to Sundać and Krmpotić's (2009) research, Croatia is at the bottom of the observed countries according to participating in the system of lifelong learning. Only 2.2\% of the population aged between 25 and 64 participate in some form of lifelong learning, and in comparison to the EU average of 9.5\%, or Finland 33\%, it is very low (Čučković and Bartlett, 2012). Babić (2005) believes that adult education in Croatia is "the most neglected and under-developed part of the education system" ${ }^{2}$. Lowther (2004) and Šošić (2004) also consider the rate of participation in lifelong learning in Croatia as very low. Šošić (2004) points out that the underdevelopment of the lifelong learning system in Croatia is particularly evident among the population older than 34 ages. Noting the problem of very low lifelong learning level in Croatia, Babić (2005), states that Croatian companies take a very little part in the financing of additional forms of education and training of its employees. Only for comparison, ET 2020 states that the share of adults participating in lifelong learning should be at least $15 \%$.

At a very poor level is Croatia according to the average number of students per 1.000 inhabitants for the period from 2002 to 2005 because there are only 27 of them, stated Sundać and Krmpotić (2009) in comparison to Austria that has 93. Šošić (2004) specifies that during the '9os the number of students has increased

52 Babić, Z., "Participacija i ulaganje u obrazovanje u Hrvatskoj." Privredna kretanja i ekonomska politika 14.101: (2005), p. 45 
about $3 \circ \%$, and the reason for such a large increase he finds in the problem of employing people with low skills, but also because of higher rate of return on investment in education. Babić, Matković and Šošić (2006) show an increase of $60 \%$ of students in 2005 in comparison to 1995 .

Sundać and Krmpotić (2009) stated that Croatia is at the bottom of the observed countries in according to the following indicators: average number of employees in the period from 2002 to 2006; numbers of employee in jobs that create knowledge or knowledge-intensive sectors of high technology research and development; numbers of researchers employed in research and development per million inhabitants. Croatia has only $3.91 \%$ of employees in jobs that create knowledge, in comparison to the average of the EU, which has $5.68 \%$ or Germany with $9.15 \%$ employees in that area. In 2006, Groatia had only 1.148 researchers, in comparison to Germany and Austria with more than 3.000 or Sweden over 6.000.

As an indicator of the use of technology, Lowther (2004) takes the number of personal computers per 1000 population, and emphasizes that this indicator suggests a significant lagging behind developed countries. Through the Population Census 2011 from the total number of households, only $55 \%$ of them have a computer. Lowther (2004) believes that the adult literacy rate is quite satisfactory, and through the Population Census 2011 the illiterate rate is only $0.8 \%$.

While researching skills that Croatian employees have, Lowther (2004) came to the conclusion that the education system allows the creation of knowledge that Croatian employers need, but there is a discrepancy between the technical employee's skills and those skills required for the specific job, which leads to a conclusion for better relation between the education an lifelong learning system with the labour market needs. Primary and secondary education, because of focusing in factual knowledge and passive learning, do not provide the acquisition of skills for the current labour market needs. Vocational high schools provide the acquisition of skills and expertise in a narrow profession area and some of professions, due to technological development, are not suitable for the current labour market needs. University programs are not sufficiently compatible with current labour market needs. Vokić and Frajlić (2004) conclude that Croatian employees are not competitive. Croatian employees are mostly older, with an average of 38 years; the average ratio of men and women is 3: 1; the average degree is slightly higher than high school; according mobility and changing jobs, Croatian workers are immobile, and the most mobile companies are foreign-owned; Croatian employees do not have a high rate of absenteeism. Subjective opinion of managers on the competitiveness of its employees was very highly rated, with mark "very good". Based on the research conducted by The Economic Institute in $2014^{5^{3}}$, Croatian companies consider the current education system is not providing adequate employee

$5^{3}$ Anić, I.D., at al., "Kako pobuditi rast Hrvatskog gospodarstva", Ekonomski institut, Zagreb, (2014) 
skills which respond to currents market needs, such as lack of practise in activities performing, lack of work habits.

Analyzing cost and benefits of education empirical research in Croatia, Šošić (2004) came to the conclusion that the rate of return on an additional year of education in 2002 was $10.5 \%$. Barić (2003), analyzing the investment decision-making in education, considers an individual decision for investing in education when it is profitable for him, which means when the net present value of benefits and costs are greater or equal to zero, or when the investments provide higher or the same return as that the investments in bank or in some other projects.

\subsection{QUALITATIVE INDICATORS}

Croatia was not involved in any international student's achievements test, and that is the reason those indicators were not involved in the previous researches. Croatia involved for the first time in PISA survey in 2006. There were a total of $6_{5}$ countries that participated, and last processed data are those from 2012. During 2015, another test was conducted, and the results will be published late in 201654. In 2011, Croatia was involved for the first time in both IEA projects: TIMSS and PIRLS, conducted by NGVO55. The rankings of Croatian students' international achievements taking parts in international testing: PISA, TIMSS, and PIRLS are listed below.

In the PISA study from 2012, except testing student's cognitive achievements, there was a survey for students, their parents, and school leaders, in order to determine the potential impact on student achievement. In the field of mathematics, Croatia is ranked 40 th. Almost 30\% of students do not have basic knowledge and skills needed to perform tasks in mathematics in different areas of life, and the highest level was reached only by $1.6 \%$ of Croatian students. Somewhat better has Croatia been ranked in the field of science; 34 th, and in reading at the $35^{\text {th }}$ place. Basic knowledge or skills, in the field of science are not owned by $17.2 \%$ of students and $18.6 \%$ in the field of reading. The highest level in the field of science and reading reached about $4 \%$ of the students. The achievements of Croatian students in all three areas are lower than the OECD average..$^{6}$

If we consider the ET2020, which gives guidance till 2020 about the proportion of those students who do not meet even the lowest level of basic skills, which should be less than $15 \%$, it can be concluded that, for now, the quality of the Croatian education system is not sufficient.

According to the results achieved in TIMMS research in the field of mathematics, Croatia is ranked 3oth and the achievements of science in the 23rd place, out of

54 http://pisa.hr/novosti/pisa-2015-glavno-istraživanje/

55 National Center for the Evaluation of Education https://www.ncvvo.hr/

56 https://www.ncvvo.hr/wp-content/uploads/2015/12/Priop $\% \mathrm{C}_{4} \% 8$ 7̨enje-za-javnost.pdf 
$5^{\circ}$ participating countries. ${ }^{57}$ Among the results achieved in PIRLS research in the field of reading, compared with the other 56 countries participating in the survey, Croatia is ranked 8th and it is ranked among the countries with excellent results. These results are comparable with those achieved by students from the USA, Ireland, or England..$^{8}$

Pastuovic (2009) commented the results of the first participation of Croatian students on international tests PISA 2006 and he considered the achievement to be very poor because they were classified in an "under average" group of countries. However, he wonders, how accurately were those achievements evaluated? He also considered that it would be best to compare those achievements with other transition countries, where the achievements of Croatia are classified in the middle, and especially for that, one should have reasons for dissatisfaction.

Čučković and Bartlett (2012) analyze the PISA 2009 results and find out some worsening of the scores especially in the field of mathematics and science, which leads them to a conclusion that Croatia needs further advancement and improvement in order to have a competitive human capital.

Pastuović (2012) thinks there is a necessity for additional analysis of factors that have contributed to these poor results, so that could introduce educational system changes. He emphasizes that, in addition to the national average, more additional information on the efficiency or inefficiency of the education system are needed, such as indicators of school average and comparison with the national average, and the impact of socioeconomic factors on the students' success all in order to gain access to establishment of measures for improving the education system.

\section{CONCLUSION}

Croatia aspires to a knowledge society. Knowledge society is based on knowledge, which Croatia obviously has not got enough for making a great impact on improving the quality of human capital. According to the data presented in this paper, Croatian educational structure is not satisfying, the results on international student's achievements tests are not satisfying, and investment in education is insufficient. Looking at Tableı, only two indicators which are considered to be satisfied (marked with *) can be noticed; such as the literacy rate (Lowther, 2004) and government expenditure in education, but only through Šošić (2004) explained. Other indicators point to below average rate, suggesting that the level of human capital in Croatia is low, and its quality is poor.

Authors indicated numerous problems, as well as gave suggestions how to increase the human capital quality, and therefore below their views and conclusions are specified.

57 http://dokumenti.ncvvo.hr/TIMSS/Dokumenti/TIMSS_2011_izvjesce.pdf

$5^{8}$ http://dokumenti.ncvvo.hr/PIRLS/Dokumenti/PIRLS_2011_izvjesce.pdf 
The Croatian educational structure is very bad, with strong low share of highly educated population that should be the leading change holder to the knowledge economy. The number of students is very small, and those with large years of study duration and high study dropout rate. Šošić (2004) believes that the long-study can be linked to difficulties in the labour market, and believes that this problem could be solved by introducing higher tuition fees. He emphasizes that such a system would be even fairer, especially concerned to taxpayers, and this because, now they are currently financing students who are going to have higher income than the average, but a third of these students is financed for nothing, because every third study is completed unsuccessfully. Pastuović (2012) refers to the damage caused by premature abandonment of formal education such as the subsequent payment of additional training, criminal behaviour caused by social exclusion, loss of revenue in the state budget because of accumulating people who do not work, the increase of underground economy.

The incompatibility of educational programs with the current labour market needs is emphasized. Lowther (2004) states that the education system needs to change from a supply-driven system to a demand-driven, which means that the education system should be able to afford various educational opportunities for all. Babić (2005), as a big problem in the secondary education system sees the mismatch of curriculum and professions and the current needs of the labour market, adding that a large number of students enrolled in those programs and occupations in which the unemployment rate is just about the greatest. Bejaković (2004) explains how the educational programs are mainly focused on memorizing basic knowledge, rather than focusing on independent analysis and conclusion. He believes that higher primary school education programs are designed more for enrolling into gymnasium, but not for vocational programs. Also, he believes that there is a need to apply a special system of dealing with gifted students. He recommends increasing the internal differentiation of students. As the main problem of primary and secondary education, he considers the insufficiency in differentiation and dropout rates.

In addition to compliance with the current labour market needs, Lowther (2004) emphasizes the need to involve citizens in the education system in the beginning of early childhood, and the need to raise their awareness about the importance of continuous improving in knowledge and skills.

The importance of recognizing education as a factor that enables citizens a better life quality, and recognition of the value of lifelong learning which is necessary to create a flexible workforce to changes in the labour market, are indicated by Sundać and Krmpotić (2009). Bejaković (2004) considers that the share of highly educated is not so far behind the developed countries, but that the level of competitiveness of the Croatian labour force is still at a low level, which he links with the mismatch of study programs and the needs of contemporary trends in the labour market.

Nikolić (2007) emphases the need for decentralization of the education system management as well as the decentralization of the system of financing educa- 
tion, which can lead to a higher quality education system, better central control over managing and financing, and therefore the higher level of human capital quality. Bejaković (2004) pointed out the need to improve the institutional framework relating to the weak effects of institutions, prevention of illegal behaviour, and increasing public confidence in the system.

The fact that, there is the necessity for reform in the education system; is clear from all indicators. Lowther (2004) believes that a big role in improving the quality of formal education has a Ministry of education through making better relations with schools, universities, and professors to develop a strategy for conducting the reform of the education system. Pasuhović (2009) considers that the objective indicators, such as the results of the international achievement tests, as well as data collected in the test, can assist in the creation of educational policy.

Unfortunately, it is not enough to invest in education for creating an acceptable level of human capital with adequate quality. It would be too simple. It is necessary to change the education system in general, but also to recognize the importance of education as a factor that can lead Croatia into a knowledge society. 


\section{REFERENCES}

Anić, I.D., at al., "Kako pobuditi rast Hrvatskog gospodarstva", Ekonomski institut, Zagreb, (2014)

Altinok, N., and Murseli, H., "International database on human capital quality." Economics Letters 96.2. Elsevier, (2007): $237^{-244}$

Andriessen, D. Stam, C., "Intellectual capital of the European Union." McOaster World Congress on the Management of Intellectual Capital and Innovation. Hamilton, Ontario, Canada, (2005)

Babić, Z., "Participacija i ulaganje u obrazovanje u Hrvatskoj." Privredna kretanja i ekonomska politika $14.101,(2005): 28-5^{3}$

Babić, Z., Matković, T., and Šošić, V., "Strukturne promjene visokog obrazovanja i ishodi na tržištu rada." Economic Trends \& Economic Policy 16.108, (2006)

Barić, Vinko. "Temeljne odrednice investiranja u obrazovanje odraslih." Pomorski zbornik 41.1, (2003): 361-379

Becker, G.S., "Human capital: A theoretical and empirical analysis, with special reference to education", 3rd Edition, University of Chicago Press, (1993)

Bejaković, P., "Konkurentnost hrvatske radne snage" Institut za javne financije, Zagreb, (2004)

Boarini,R., D’Ercole, M.M., and Liu, G., "Approaches to Measuring the Stock of Human Capital: A Review of Country Practices", OECD Statistics Working Papers, No. 2012/04, OECD Publishing, Paris, (2012)

Bogdanović, M., "Prilog teoriji ljudskog kapitala: Koja svojstva radne snage treba smatrati bitnim sastavnicama ljudskog kapitala ", Ekonomija / Economics 15.1, (2008): 45-81

Bontis, N., "National intellectual capital index: the benchmarking of Arab countries" Journal of Intellectual Capital 5.1: 13-39, (2004)

Council conclusions of 12 May 2009 on A Strategic Framework for European Cooperation in Education and Training (ET 2020) (2009/G 119/o2)http://eur-lex.europa.eu/legalcontent/EN/TXT/PDF/?uri=CEL $\mathrm{EX}: 52009 \mathrm{XGo} 28$ (01)\&from=EN

Croatian Bureau of Statistic: 1) Yearbook 2005 http://www.dzs.hr/Hrv_Eng//jetopis/2005/26-met. pdf2) Population Census 2011 http://www.dzs.hr/Hrv/censuses/census2011/results/htm/ho1_01_36/ hol_o1_36_RH.html

Čučković, N. and Bartlett, W., "Skills Matching in Croatian SME sector and competence based education and training: progress and prospects." Labour Market and Skills in the Western Balkans, FREN Belgrade and LSE London, (2012): 155-175

European Statistical System (ESS) http://ec.europa.eu/eurostat/web/european-statistical-system

Eurostat Regional Yearbook 2014 http://ec.europa.eu/eurostat/documents/3217494/5786237/KS-HA14- - o 1-o3-EN.PDF/43efce65-4,b6c-41105-8c93-a6fce178c5ee?version=1.0

Filipić, P., "Makroekonomija gubljenja statusa redovitog studenta ili fiskalne posljedice (ne) položenog ispita." Financijska teorija i praksa 33.1, (2009): 1-23

Hanushek, E.A. and Kimko, D.D., "Schooling, Labor-Force Quality, and the Growth of Nations", American Economic Review, 90 (5), (2000): 1184-1208

Horvat Novak, D., and Hunjet, A., "Analiza učinkovitosti visokog obrazovanja u Republici Hrvatskoj." Tehnički glasnik 9.4, (2015):461-468 
Human development Report 2015 Team, Work for Human Development, United Nations Development Programme (UNDP), New York http://hdr.undp.org/sites/default/files/2015_human_development_ report.pdfhttp://hdr.undp.org/en/countries

International Association for the Evaluation of Educational Achievement www.iea.nl http:// timssandpirls.bc.edu/http://timss.bc.edu/timss2011/downloads/T11_IR_Mathematics_FullBook.pdf http://timss.bc.edu/pirls2011/downloads/P11_UserGuide.pdf

International Labour Organization http://www.ilo.org/global/publications/books/forthcomingpublications/WCMS_4.09035/lang--en/index.htm

Kiss, I., "Financiranje obrazovanja u Europi i u Republici Hrvatskoj." EKONOMIJA / ECONOMICS 1/IX, (2002) www.rifin.com

Kwon, Dae-Bong, "Human capital and its measurement." Proc. The 3rd OECD World Forum on Statistics, Knowledge, and Policy, (2009)

Lee, J. W. and Barro, R. J., "Schooling Quality in a Cross Section of Countries", Economica, 38(272), 465488, Wiley Online Library, (2001)

Lowther, J., "Kvaliteta hrvatskoga formalnog obrazovnog sustava." Deloitte Touch Tohmats, Washington, (2004), http://www. ijf. hr/konkurentnost/lowther. pdf

Mankiw, N. G.,"Principles of economics", Mason, Ohio: Thomson/South-Western, (2004)

Miller, R., "Measuring What People Know: Human Capital Accounting for the Knowledge Economy", Paris: OECD Publishing, (1996)

National Center for the Evaluation of Education https://www.ncvvo.hr/https://www.ncvvo.hr/wpcontent/uploads/2015/12/Priop\%C4\% \%87enje-za-javnost.pdfhttp://dokumenti.ncvvo.hr/TIMSS/ Dokumenti/TIMSS_2011_izvjesce.pdfhttp://dokumenti.ncvvo.hr/PIRLS/Dokumenti/PIRLS_2011_ izvjesce.pdf

Nikolić, N., "Financijska decentralizacija obrazovnog sustava u Hrvatskoj." Ekonomska misao i praksa 2, (2007): 213-228

OECD, Education at a Glance 2014 http://www.oecd.org/edu/Education-at-a-Glance-2014.pdf, Education at a Glance $2013 \mathrm{https}$ ://www.oecd.org/edu/eag2013\%20(eng)--FINAL\%2020\%20June\%20 2013.pdf

Pasher, E., and Shachar, S., "The intellectual capital of the state of Israel: 60 years of achievement." Prieiga perinternetš: http://www. moital. gov. il/ic, (2007)

Pastuović, N., "Edukologija: integrativna znanost o sustavu cjeloživotnog obrazovanja i odgoja", Znamen, Zagreb, (1999)

Pastuović, N., "Obrazovanje za razvoj: Kako obrazovanje razvija ljude i mijenja društvo, a kako društvo djeluje na obrazovanje", Zagreb: Institut za društvena istraživanja u Zagrebu: Učiteljski fakultet Sveučilišta uZagrebu, (2012)

Programme for International Student Assessment PISA www.pisa.hr http://pisa.hr/novosti/pisa-2015glavno-istraživanje/

Pološki, V., N., and Grizelj, H., "Obrazovanje i razvoj zaposlenika u hrvatskim organizacijama." Ekonomski pregled 58.12, (2007): $85^{1-880}$

Požega, Ž. and Crnković, B.,"Stope povrata od ulaganja u ljudski i fizički kapital." Ekonomski Vjesnik/

Econviews: Review of contemporary business, entrepreneurship, and economic issues 21.1-2, (2008): 67- $\eta^{3}$ 
Raguž, I., Družić, I., and Tica, J., "Impact of the transition on the TFP in Croatia." EFZG Working Paper Series/EFZG Serija članaka u nastajanju 05, (2012): 1-26

Schultz, Theodore W., "Investment in human capital", The American Economic Review 51.1, (1961): 1-17

Schultz, Theodore W., "Investing in people: The economics of population quality", University of California Press, (1982)

Stengos, T., and Savvides, A., "Human capital and economic growth", Stanford University Press, Stanford, (2009)

Structure of the European Education Systems 2014/15: Schematic Diagrams, European Commission, $\mathrm{http}$ ://eacea.ec.europa.eu/education/eurydice/documents/facts_and_figures/education_structures_ EN.pdf

Sundać, D., and Krmpotić, Fatur I., "Vrijednost ljudskog kapitala u Hrvatskoj - usporedba s odabranim europskim zemljama." Ekonomski pregled 60.7-8, (2009):315-331

Šćukanec, N., Sinković, M., Bilić, R., Doolan, K. i Gvitan, M. "Socijalni i ekonomski uvjeti studentskog života u Hrvatskoj: nacionalno izvješće istraživanja EUROSTUDENTV za Hrvatsku za 2014.", Zagreb: Ministarstvo znanosti, obrazovanja i sporta, (2015)

Škare, M., "Human Capital as a Source of Growth-Myth or Reality?." Ekonomski pregled 52.1-2, (2001): $189-205$

Škare, M., Kostelić, K., Justić Jozičić, K., "Does Higher Education Pay off? - Micro an Macroeconomic Policy Implications"; The future of economics: Between rules and discretion; Juraj Dobrila University of Pula, (2013): $93-120$

Šošić, V., "Isplati li se u Hrvatskoj ulagati u obrazovanje: povrat ulaganja u ljudski kapital kao čimbenik konkurentnosti ljudskih resursa ", Institut za javne financije, (2004) http://www.ijf.hr/konkurentnost/ sosic.pdf

Tica, J. and Đukec, D., "Doprinos ljudskog kapitala ekonomskom rastu u Hrvatskoj." Zbornik Ekonomskog fakulteta u Zagrebu, 6.1, (2008): 289-301

Tica, J., and Grgurev, I., "Relativna važnost faktora rasta u Republici Hrvatskoj." EFZG Working Paper Series/EFZG Serija članaka u nastajanju o2, (2014): 1-16

UNESCO Institute for Statistic http://data.uis.unesco.org/?querid=181

UNICEF, http://www.transmonee.org/databases.php TransMonEE 2015 Database, Country profiles 2015

Vokić, P., N., and Frajlić, D., "Pokazatelji konkurentnosti hrvatske radne snage: rezultati empirijskog istraživanja, iz Bejaković." P., Lowther, J. ur.: Konkurentnost hrvatske radne snage, Institut za javne financije, Zagreb, (2004): 59-74

Wu, M., "Comparing the Similarities and Differences of PISA 2003 and TIMSS. OECD Education Working Papers, No. 32." OECD Publishing (NJ1), (2010), http://www.oecd.org/officialdocuments/publicdisplayd ocumentpdf/?doclanguage $=\operatorname{en} \& \operatorname{cote}=\operatorname{edu} / \mathrm{wkp}(2010)_{5}$ 
